\title{
The Effect of Knowledge Management Uses on Total Quality Management Practices: A Theoretical Perspective
}

\author{
Bader Yousef Obeidat $^{1}$, Lama Hashem ${ }^{1}$, Iman Alansari ${ }^{2}$, Ali Tarhini ${ }^{3} \&$ Zahran Al-Salti $^{3}$ \\ ${ }^{1}$ Business and Management Department, The University of Jordan, Amman, Jordan \\ 2 Department of Computer Science, Taibah University, Medina, Saudia Arabia \\ ${ }^{3}$ College of Economics and Political Science, Department of Information Systems, Sultan Qaboos University, \\ Muscat, Sultanate of Oman \\ Correspondence: Ali Tarhini, College of Economics and Political Science, Department of Information Systems, \\ Sultan Qaboos University, Muscat, Sultanate of Oman. Tel: 974-5012-1922.
}

Received: August 16, 2016

Accepted: August 29, 2016

Online Published: October 28, 2016

doi:10.5430/jms.v7n4p18

URL: http://dx.doi.org/10.5430/jms.v7n4p18

\begin{abstract}
Previous studies have showed that selecting the influential factors related to knowledge management (KM) uses and total quality management (TQM) practices has been always a critical task for researchers. To the best of the authors' knowledge, there are few papers that review the concept of knowledge management uses on total quality management practices. Based on a comprehensive literature review, this study aims to highlight the important factors related to knowledge management uses on total quality management practices. This study identified knowledge acquisition, knowledge storage, knowledge transfer and knowledge application as the most important knowledge management uses. While customer satisfaction, training and employees education, commitment of top management, team work and continuous improvement were considered to be the most important TQM practices. This study provides a holistic picture for future researchers in selecting the popular related KM uses and TQM practices. This will help them build a strong knowledge in this area in order to develop theoretical basis for their future research.
\end{abstract}

Keywords: knowledge management, total quality management, literature review

\section{Introduction}

In the past two eras, absence of knowledge prevailed two times: first, when a great number of employees were fired as a result of reducing their numbers and consequently, most of the needed knowledge was not available in the organizations (Abbasi et al, 2015; Alenezi et al, 2015). Second, when machines started to take the place of human workers in production lines. So, organization flexibility became absent (Obeidat et al., 2014). Just like knowledge itself, knowledge management is difficult to define (Al-Busaidi, 2010). The working definition of knowledge is that knowledge must involve an agent, who uses it to perform the actions necessary to reach a goal (Abu-Shanab et al, 2014). Knowledge can and should be assessed by the choices or activities to which it leads (El-Masri et al., 2015; Altamony et al., 2016). Though, describing what knowledge management understands may be somewhat unpretentious than defining knowledge on its own. The idea of management gives us a preliminary idea when considering, for example, the actions that make it up, clarifying the procedures for creating and displaying its key objectives without the need to express what is understood by knowledge. Therefore, there are more concepts and explanations on knowledge management than just on knowledge (Masa'deh et al., 2015), while these are not always clear as there are many expressions associated with the concept (Al-Busaidi \& Olfman, 2005; Lloria, 2008).

The effective adoption of KM in an organization works as a change agent that could simplify the achievement and development of quality practices (Al-Salti \& Hackney, 2011). But to confirm the achievement in launching a KM initiative, the first thing to do, is to learn from the successful and unsuccessful implementation of total quality management (Shannak et al., 2014). The second thing to be aware of is that $80 \%$ of the efforts of a KM initiative must be made on the people aspect of it and only $20 \%$ of efforts needs to be dedicated to technology (Hajar et al., 2016). Technology is an enabler for successful KM as well as a catalyst for its emergence (Wilson, 2010).

Knowledge serves several capacities, such as complexity, ancient sense, judgment and elasticity which considered as an important tool to achieve success in a highly fast growing global economy. On the other hand, total quality 
management (TQM) may be defined as a holy organization philosophy which seeks always to be upright in organizational improvement (Kaynak, 2003). When leaders of a society want to reflect the idea of knowledge management, they must develop precise policies in accordance with that idea and provide the staff with adequate needed capitals (Masa'deh et al., 2016). However, the leaders can neither control the course of the knowledge nor control to what degree they are following these policies. The only thing they can do is to inspire the workers to follow the selected strategies or encourage them to self-organize and how they should work with knowledge management (Danish et al. 2014). There is no single path to achieve total quality within an organization. There are no hard and fast rules to follow to become a world class company. The only constants are basic guidelines, that, when followed, lead to success. This is because all organizations have their own cultures, people, and technologies. What may work well for one company will not necessarily work for another (Pekar, 2005).

To the best of the authors' knowledge, there are few papers that review the concept of knowledge management uses on total quality management practices. Based on a comprehensive literature review, this study aims to highlight the important factors related to knowledge management uses on total quality management practices. This study provides a holistic picture for future researchers in selecting the popular related KM uses and TQM practices. This will help them build a strong knowledge in this area in order to develop theoretical basis for their future research.

The rest of the paper is organized as follows. Section 2 provides a review of the literature related to the concept of knowledge management and identify the most important KM uses in the literature. Section 3 reviews the concept of total quality management. Before concluding the paper in section 5, section 4 study the relation between KM uses and TQM practices.

\section{Knowledge Management (KM)}

The participation incompetent knowledge is an advantage for achieving success (Masa'deh et al., 2016). Hence, great attention must be given to proper methods of knowledge management, $\mathrm{KM}$ is just like the absolute knowledge, difficult to define (Al-Busaidi et al., 2010). The proper definition of knowledge must involve an agent, who uses knowledge to perform the necessary actions to reach a goal (Obeidat et al., 2016). Knowledge must be evaluated according to decisions and actions which will lead to achieving success (Davenport and Pruzak, 1998). However, as mentioned before, defining what involves knowledge management may be easier than defining knowledge in general. The subject matter of management provides us a starting point when considering, for instance, the activities which make it successful, explaining the processes of innovation or showing its main goals and objectives without the need to define what is understood by knowledge. However, in literature there are many ideas and definitions for KM than just on the absolute knowledge, although these definitions are not always clear as there are many terms related to the concept (Loria, 2008). KM is a significant factor for organizations to make sound decisions about how and when to come up with new acknowledges and utilize it in its activities (Frey, 2001). Accordingly, the role played by knowledge management through operations and practice achieve great results in the regulatory area as being the factors which enrich and enhance productivity (Shannak et al., 2012).

The number of definitions for knowledge management which researchers have come up with reflects their views toward the way they conduct their activities. Knowledge management deals with any intentional set of practices and processes designed to optimize the use of knowledge, in other words, to increase allocative efficiency in the area of knowledge production, distribution and use" (Young, 2013, p. 3). Also knowledge management is "the process of capturing, organizing, and storing information and experiences of workers and groups within an organization and making it available to others (Masa'deh et al., 2016). Knowledge management is also defined as a set of activities organized by which is to find the best combination and linking of information and intellectual resources, by entering a room focused and complex operations, which include access to the underlying and the implicit of the human mind knowledge and turn it into knowledge of the phenomenon can be stored and shared with beneficiaries, and then apply the best, to be the competitive ability of the organization (Frey, 2001, p.39). Cheung et al (2008) view the concept of $\mathrm{KM}$ from the perspective of the customer service management, as has been represented in the form of a pyramid of three layers: First layer: data assimilation and public information services which provide services to customers on the data and information form, any knowledge of the phenomenon of support for the decisions they make, as in most of the banks. The second layer: Consulting services which provide customers with advisory services with proposed solutions to the problems, and use knowledge-based industrial in the system design systems. The third layer: knowledge and service managers and no experience in organizations that provide their customers experience, and specialists here have to keep up that business developments, and the ongoing work of the quality of service improvements.

Although knowledge is a complicated concept to be defined and measured, the definitions of knowledge range from 
conceptual to practical and from narrow to broad (Masa'deh et al., 2015). Then knowledge will be defined as truth, beliefs, personal experience, information, and data (Wiig, 1993; Yang, 2003). The concentration in this study is on the definition that covers the most aspect of knowledge which defines knowledge as "a fluid mix of framed experience, values, contextual information, and expert insight that provides a framework for evaluating and incorporating new experiences and information" (Davenport and Prusak, 1998, p.5).

Hibbard (1997) assumed as a fact that KM to be the process of apprehend, an organization's collective expertise and distribute it in order to come up with the best of it as much as possible. According to Tiwana (2010), KM is the supervision of creative knowledge to place commercial values and lead to a reasonable advantage. KM simplifies the conception, communication, and request of all types of knowledge to attain business objectives. Darroch and McNaughton (2005) considered that knowledge management is the management purpose that generates, detects, and manages the idea of knowledge within a society to encompass that knowledge is used efficiently for the long-term benefits of the organization. As a result, KM is a policy of granting the right knowledge to the right people in a timely manner to help people share and put that knowledge into action in ways that attempt to expand organizational performance (O’Dell and Grayson, 2008; Tayal, Coleman \& Li, 2013).

The description which was adopted is that knowledge management discusses a methodical and integrative procedure that helps organizations to find, organize, allocate and transfer important evidence, knowledge, and expertise which is essential for actions such as problem resolving, self-motivated learning, strategic planning, and decision-making to accomplish the goals of the organization (Gupta et al. 2000; Danish et al. 2014).

Based on extensive review of previous research, the following Knowledge Management Uses are considered to be the most important uses (knowledge acquisition, knowledge storage, knowledge transfer and knowledge application).

\subsection{Knowledge Acquisition}

Pacharapha and Vathanophas (2012) defined knowledge acquisition as the process of the development and creation of insight, skill and relationships. For knowledge to be acquired, there should be willingness and ability of a recipient to acquire and use knowledge are crucial elements (Gupta, 2000). During the process of knowledge acquisition, it is important that both source and recipient should be willing to share. There are five motivational drivers that should be taken into consideration: attitude towards knowledge sharing, cost and benefit, subjective norms and organizational climate and perceived value of knowledge (Ford and Staples, 2010). Knowledge acquisition envisages learning from others through interaction between recipient and source. Nonaka and Takeuchi (1995) opine that the SECI (socialization, externalization, combination, and internalization) and models play important roles in knowledge acquisition through interaction and collaboration with other individual systems. In knowledge-intensive institutions such as banks, enabling environments are envisaged that allow different departments or individuals to acquire insight, skill and relationships. Management should counter the silo mentality and allow departments to share information, notwithstanding the privacy and secrecy policies of banks. Training and development programs inherent in banks should pave ways for knowledge acquisition, which is consistent with the SECI and models. So knowledge acquisition is the process used to define the rules and ontologies required for a knowledge-based system. The phrase was first used in conjunction with expert systems to describe the initial tasks associated with developing an expert system, namely finding and interviewing domain expert and capturing their knowledge via rules, objects, and frame-based ontologies.

\subsection{Knowledge Storage}

Ernst and Young (1998) refer to knowledge management as an expansion of procedures which tie knowledge application to business strategies. The related signification is given by Debowski (2006) who has stated that KM is a procedure of finding, taking, organizing and distributing the intelligence assets to achieve maintainable organizational performance. KM is also defined as a procedure which helps business to recognize, select, establish and hand over critical information which resides within the organization (Turban, 2011). Stein and Zwass (2005) have highlighted that storage and retrieval of organizational knowledge are referred as administrative memory which includes knowledge residing in numerous form such as written records, documented managerial policies and measures, and organized knowledge stored in database, data warehouse or other business intelligence tools. So knowledge storage is the process of recognizing new information as relevant and essential for current and future use and storage it in reasonable forms so that anyone in the organization can access it.

\subsection{Knowledge Transfer}

Knowledge transfer is the knowledge wherever the data recipient acquires identical data because the data supplied and internalizes the data to create his/her new data (Krogh and Roos, 2005). The basic framework needed to research 
information transfer among a corporation involves three areas of interest: the information characteristics, the activities of information transfer, and also the actual transfer performance (Cummings, 2002). Knowledge transfer performance includes such aspects as knowledge sharing (Tsai, 2011), knowledge flow (Gupta, 2000). Supported these premises, the influencing factors on data transfer embody structural factors of front/back workplace, like structure and structure distance, psychological feature factors like common understanding, data distance, and data sharing, and factors within the relative dimension, like relationship quality and credibleness. This can be kind of like the essential analytical framework of the Social Capital Theory, that is additionally applicable within the analysis of structured data transfer. So information transfer is that the sensible drawback of transferring information from one a part of the organization to a different. Like information management, information transfer seeks to arrange, create, capture or distribute information and guarantee its availableness for future users. Information transfer is additional complicated as a result of information resides in structure members, tools, tasks, and their sub networks and far information in organizations is understood or arduous to articulate.

\subsection{Knowledge Application}

Knowledge application or reuse to decision-making processes, related to business strategy, task implementations, service delivery, and organizational performance and effectiveness. Knowledge application processes are those processes oriented toward the actual use of knowledge (Gold et al., 2001). Wiig (1997) noted that the value of knowledge assets is realized when the assets are used to create products or deliver services, or when they are sold or traded for value. Davenport (1998) also argued that the effective application of knowledge has helped companies improve their efficiency and reduce costs. Furthermore, Alavi and Leidner (2001) noted that while the processes of knowledge creation, storage/retrieval, and transfer do not necessarily lead to enhanced organizational performance, effective knowledge application does. The underlying assumption is that if an organization does not find it easy to locate the right kind of knowledge in the right form, the organization may find it difficult to sustain its competitive advantage.

\section{Total Quality Management (TQM)}

Total quality management is a management viewpoint that pursues to incorporate all organizational purposes (marketing, finance, design, engineering, and production, customer service, among other characteristics) to emphasis on gathering customer needs and organizational objectives (Bemowski, 1992; Obeidat et al., 2016). TQM is a technique by which management and employees can become involved in the continuous development of the construction of goods and services. It is a mixture of quality and management tools targeted at increasing business and decreasing losses due to wasteful performs. Quality management not only emphases on product and service quality, but also on the means to achieve them. Total quality management is defined as "a management approach of an organization, centered on quality, based on participation of all members and aimed at long-term success through customer satisfaction, and benefits to all members of the organization and the society"(ISO 8402:1994). TQM is a constant procedure of development for individuals, and the whole organization. Commercial organizations yield a product that is intangible. Usually, the completed product cannot be seen or touched; rather, it is experienced (Wang and et al, 2012).

The immaterial nature of the product makes defining quality a hard task. Also, since a check is experienced, sensitivities can be highly subjective. In addition to tangible factors, quality of services is often defined by perceptual factors. These include responding to customer needs, courtesy and friendliness of staff, promptness in resolving complaints, and atmosphere. Other definitions of quality in the services included time-the amount of time a customer has to wait for the service; and consistency-the degree to which the service is the same each time. For these reasons, defining quality in services can be especially challenging (Hales, 2010).

TQM is extensively recognized as a management attitude. Many controversies exist regarding the fundamentals, planned by different investigators and professionals in relation to TQM. These fundamentals do not fully coincide, and not all such fundamentals that compose the total quality management theoretical framework can be called TQM without management factors being applied in the organizations where they are based (Montes et al., 2003). TQM focuses on constant process development within organizations to provide larger customer value and meet customer needs. Meeting customer needs includes company processes focused on accepting, sharing, and replying to customers through marketing concept. Firms approving and applying the marketing concept are said to display a market orientation (Wanga and et al, 2012).

Total quality management is a comprehensive concept and has numerous definitions. Deming (1986) and Crosby (1996) concerned that customers define quality and so, quality produces customer satisfaction leading to a better competitive position. They further stressed that, in combination with customer focus, the elimination of the high 
costs of waste, and rework are equally important to the organization in achieving its strategy. Antony et al. (2002) and Maguad (2006) added that besides meeting customer pleasure, the highlight of total quality management is about more than customer expectation, continuously improvement, and long-term organizational success. It includes problem prevention, process improvement, and a team-based approach to problem solving and product improvement incorporating all departments in the organization.

Total quality management is one of numerous quality-based methods, began in Japan after the Second World War and spread to USA in the 1980s, mostly in US manufacturing companies facing competition from Japan (Easton \& Jarrell, 1998). When fully assumed and efficiently practiced, total quality management conveys many advantages, including improving employees involvement, improving infrastructures, increasing efficiency, improving quality and less rework, enhance customer satisfaction, decreasing the cost of poor quality, and strengthening the organizational business performance and competitive advantage (Antony et al. 2002).

Based on extensive review of previous studies, the following TQM practices are considered to be the most important practices. The following subsections discuss these practices:

\subsection{Customer Satisfaction}

Rai (2013) defined satisfaction as a buyer's emotional or cognitive answer to be post-subjective assessment then comparing pre-purchase expectations with normal performance subsequent by consuming the good or service, as evaluating the expenses incurred and benefits reaped in a definite purchase over or even time relating to transacting with an organization. Most studies highlight the significance of customer satisfaction. For example Kassim and Abdullah (2010) mentioned that the customer happiness is a vital tendency to develop the managerial performance. Fotopoulos and Psomas's (2010) study also reflects that customer focus and satisfaction are positively and significantly related to the performance of the organization. While Chen et al. (2014) assured that perfect-established relationship among clients would increase financial and financial product. At the same time Dadfar et al. (2013) indicate that it is necessary to build an effective relationship with the clients and service producer in order to produce an efficient co-as well as production.

\subsection{Training and Employees Education}

Training and Education Employees is the most important factor in any institution even if this institution includes a small or a big number employee (Silva, 1997). Better employees most of the time leads to good performance. To achieve this, companies should educate their staff through training them to help them get the latest skills and knowledge which will lead to a better efficient and effective workplace (Cervená, 2011; Al-Sarayrah et al., 2016). International and fashionable amendment in technology desires innovative technique of providing education and coaching programs for workers (Vargas \& Tian, 2013). Coaching refers to a planned effort by an organization to facilitate employees learning of job-related competencies, as well as information, skills, or behaviours that are vital for winning job performance (Mondy, 2013). Coaching and education creates productive staff and helps in increasing employee's skills and information to extend job satisfaction (Gagnon et al., 2013).

\subsection{Commitment of Top Management}

It is "a force that binds an individual to a course of action of relevance to one or more targets" (Meyer \& Herscovitch, 2011, p.299). Top management commitment plays a significant role in constructing trust with staff. It should transcend adopting slogans of rising quality, so become a lot of concerned in quality efforts at numerous designing and implementation and observation phases. High level managers should target developing people's skills and capacities through the engagement of workers in many varieties of coaching programs, which give the organization with a skillful sales-force and promoting team (Jones and Grimshaw, 2012). Moreover, high level managers should involve all staff within the construction and style stages to be ready to meet the expectations of stakeholders, customers, and to achieve a high level of quality and satisfaction (Pencarelli et al., 2013). Managers ought to have profound data of TQM, a disposition to actively participation and enthusiasm. They have clearly outlined terms permanently understanding of the work; otherwise staff could develop their own definitions which could result in unfavorable outcomes for organizations and stakeholders (Sanzo et al., 2012).

\subsection{Team Work}

Teamwork was defined as a "process to fulfill the employee's need for control over their work environment" (Doorewaard, 2012, p.81). It holds a common task requiring interdependent work and action (Thompson, 2011). Subsequently cooperation may be a set of activity skills operating along to come up with best outcomes (Hughes and Jones, 2011). Cooperation is an important facet for the success of the organization. It leads the organization to speak with the goal and mission of the organization, encourages ability, shares data, builds trust and openness and 
empowers staff (Gupta et al., 2001). Salas et al. (2010) found that cooperation helps maintain a competitive advantage within the face of challenges caused by many world events and conjointly by international marketplaces.

\subsection{Continuous Improvement (CI)}

CI was seen as binary, i.e. no CI or CI (Bessant et al, 2001), but it is increasingly considered as an evolutionary process where organizations reaches different levels as continuous improvement work matures (Bessant et al, 2001, Gertsen, 2001). For instance, Bessant et al (2001) proposed that the ultimate level of CI is the learning organization. Linking continuous improvement and learning is essential for facilitating organizational change processes (Busk-Kofoed et al, 2002) and the ultimate goal is to build a learning organization (Liker \& Hoseus, 2010). Related to this is that managers at companies that successfully implement continuous improvement tend to have a process oriented focus, whereas managers at less successful firms had a result-oriented focus. Explanations for the detected differences is that process oriented managers tend to be more patient and focus on constant improvements that render long-term improvements (Liker \& Hoseus, 2010). Moreover, Davidson et al. (2006, p. 197) argued that CI is "more than a manufacturing approach, it needs to be a way of life", while Ehie and Sheu (2005) put a greater emphasis on CI in relation to methods such as six sigma and theory of constrains that improves manufacturing system performance. Rather than emphasizing philosophy or method used, this view stresses output in relation to the probability that improvements will continue over time. Others emphasize that continuous improvement must be a bottom-up approach such as Gertsen (2001, p. 304) who argues that CI is "an improvement process that is systematically applied, carried out in small steps, and to a large extent relies on employee participation". All in all, there are different elements of continuous improvement and key elements include context in which improvements take place (i.e. manufacturing), kind of improvement that is realized (i.e. small steps), how it is realized (i.e. endurance, systematic principles), and by whom (i.e. employee participation). In fact, it is plausible to argue that a CI definition, as well as practical work, must entail all these elements if changes are going to improve organizational performance. In addition, the employees, creativity and knowledge are the basis for continuous improvement (Liker \& Hoseus, 2010). TQM is mainly concerned with constant improvement in all work, from high level planned planning and decision-making, to full execution of work elements. The defects can be prevented, as they lead to continuously improving results of people, processes, and technology (Ijaz et al., 2012). The continuous improvement may be a dynamic method, specialize in improvement programs, services, materials and their relationship with the organization's customers, suppliers, competitors, and capital markets (Singh, 2013).

Consistent with Besterfield (2003), total quality management practices contain instilling a quality culture, the so-called quality chain (treating each element as a customer and producer simultaneously), quality assurance, commitment to continuous improvement, and the support of top management. Furthermore, total quality management principles cover a planned link to the organizational objectives, recognizing customers and understanding their prospects, employees' contribution, top management provision, and continuous improvement. Oakland and Porter (2004) planned a new generation of total quality supervision concentrating on relationships between hard and soft foundations. The soft substance, including effective management, commits to meet customer necessities, communicates the quality message and recognizes the need to change the culture, achieve total quality, and encase the hard basics (four Ps), which is consisting of planning, performance, process, people, and to ensure successful implementation (Oakland and Porter, 2004).

\section{Knowledge Management- Total Quality Management Relationship}

Few researchers recently expressed their interest in the relationship of TQM and KM, but, they have not achieved a consensus toward conceptualizing this relation. These practical studies are the ones conducted by (Molina et al., 2007; Hung et al., 2011) considered this relationship related to innovation. However, these results have different settings in respect of the nature of the relationship. Hung et al., (2010) showed that TQM is a mediator in the relationship between KM and innovation, while Molina et al., (2007) considered knowledge transfer as a mediator between TQM and performance. However, in respect of the methodical aspect of the mediator concept, the mediator represents the general mechanism by which the focal independent variable is able to influence the dependent variable of interest. These results assure credibility of the relate literature of the relationship. On the other hand, some researchers considered KM as a facilitator to TQM (Barber et al., 2006; Stewart Waddell, 2008) while other scholars concerned TQM as an antecedent of KM (Lin and wu, 2005; Molina el al., 2007; Choo el al., 2007; Colurcio, 2009; Jayawara and Holt, 2009). The relationship between TQM and KM understood in different ways. From one perspective $\mathrm{Km}$ is determined as an activator to TQM. Stewart and Waddell (2008) said that widening the concept of quality for product and service specifications as a quick response to customer needs, clear the relationship between $\mathrm{KM}$ and TQM. Gaining the knowledge and spreading it brings about a quality culture which creates understandable 
frame work according to quality programs and KM.

On other hand, there are many approaches supposes that TQM is a supporter for KM. Lin and Lee (2005) presented ISO 9000 process-based knowledge management system architecture, which support knowledge flow in the organization. Colurcio (2009) in a case study research revealed that TQM practices are facilitators of Knowledge Creation and dissemination. Choo et al. (2007) introduces a conceptual framework based on quality programs and KM. Jayawarana and Holt (2009) analyzed the relationship between knowledge creation and transformation in the research and development context. Based on their case study research, they concluded that TQM practices improve knowledge creation and transformation. In an empirical study that was conducted by Molina et al. (2007), the relationship between TQM practices and knowledge transformation is examined.

\section{Conclusion}

Previous studies showed the selection of an influential factor has been always a critical task for researchers. To the best of the authors' knowledge, there are few papers that review the concept of knowledge management uses on total quality management practices. Based on a comprehensive literature review, this study aimed to highlight the important factors related to knowledge management uses on total quality management practices. Based on a comprehensive review, knowledge acquisition, knowledge storage, knowledge transfer and knowledge application were considered to be the most important knowledge management uses. While customer satisfaction, training and employees education, commitment of top management, team work and continuous improvement were found to be the most important TQM practices. This study provides a holistic picture for future researchers in selecting the popular related the KM uses and TQM practices. This will help them build a strong knowledge in this area in order to develop theoretical basis for their future research.

\section{References}

Abbasi, M. S., Tarhini, A., Elyas, T., \& Shah, F. (2015). Impact of individualism and collectivism over the individual's technology acceptance behaviour: A multi-group analysis between Pakistan and Turkey. Journal of Enterprise Information Management, 28(6), 747-768. http://dx.doi.org/10.1108/JEIM-12-2014-0124

Abu-Shanab, E., Haddad, M., \& Knight, M. B. (2014). Knowledge sharing practices and the learning organization: A study. IUP Journal of Knowledge Management, 12(2), 38-50.

Alavi, M., \& Leidner, D. E. (2001). Review: Knowledge management and knowledge management systems: Conceptual foundations and research issues. MIS quarterly, 25(1), 107-136. http://dx.doi.org/10.2307/3250961

Al-Busaidi, K. A. (2010). The Impact of Supporting Organizational Knowledge Management through a Corporate Portal on Employees and Business Processes. International Journal of Knowledge Management, 6(3), 44-64. http://dx.doi.org/10.4018/jkm.2010070103

Al-Busaidi, K. A., \& Olfman, L. (2005). An investigation of the determinants of knowledge management systems success in Omani organizations. Journal of Global Information Technology Management, 8(3), 6-27. http://dx.doi.org/10.1080/1097198X.2005.10856400

Al-Busaidi, K. A., Olfman, L., Ryan, T., \& Leroy, G. (2010). Sharing Knowledge to a Knowledge Management System: Examining the motivators and the benefits in an Omani organization. Journal of Organizational Knowledge Management, 201(25835), 1-12

Alenezi, H., Tarhini, A. \& Sharma, S. K. (2015). Development of a Quantitative Model to Investigate the Strategic Relationship between Information Quality and e-Government Benefits. Transforming Government: People, Process and Policy, 9(3), 324-351. http://dx.doi.org/10.1108/TG-01-2015-0004

Almajali, D. A., Masa'deh, R., \& Tarhini, A. (2016). Antecedents of ERP Systems Implementation Success: A Study on Jordanian Healthcare Sector. Journal of Enterprise Information Management, 29(4), 549-565. http://dx.doi.org/10.1108/JEIM-03-2015-0024

Al-Salti, Z., \& Hackney, R. (2011). Factors impacting knowledge transfer success in information systems outsourcing. Journal of Enterprise Information Management, 24(5), 455-468. http://dx.doi.org/10.1108/17410391111166521

Al-Sarayrah, S., Obeidat, B.Y., Al-Salti, Z., \& Kattoua, T. (2016). The Effect of Culture on Strategic Human Resource Management Practices: A Theoretical Perspective. International Journal of Business Management and Economic Research, 7(4), 704-716

Altamony, H., Al-Salti, Z., Gharaibeh, A., \& Elyas, T. (2016). The relationship between Change Management Strategy and Successful Enterprise Resource Planning (ERP) Implementations: A Theoretical Perspective. 
International Journal of Business Management and Economic Research, 7(4), 690-703.

Antony, J., Leung, K., Knowles, G., \& Gosh, S. (2002). Critical success factors of TQM implementation in Hong Kong industries. International Journal of Quality \& Reliability Management, 19(5), 551-566. http://dx.doi.org/10.1108/02656710210427520

Baker, M.J. (2014). Marketing Strategy and Management (2nd ed.). Macmillan Basingstoke.

Barber, K. D., Munive-Hernandez, J. E., \& Keane, J. P. (2006). Process-based knowledge management system for continuous improvement. International Journal of Quality \& Reliability Management, 23(8), 1002-1018. http://dx.doi.org/10.1108/02656710610688185

Bemowski, K. (1992). The quality glossary. Quality progress, 25(2), 18-19.

Bessant, J., Caffyn, S., \& Gallagher, M. (2001). An evolutionary model of continuous improvement behaviour. Technovation, 21(2), 67-77. http://dx.doi.org/10.1016/S0166-4972(00)00023-7

Chen, C. J., Huang, J. W., \& Hsiao, Y. C. (2010). Knowledge management and innovativeness: The role of organizational climate and structure. International Journal of Manpower, 31(8), 848-870. http://dx.doi.org/10.1108/01437721011088548

Chen, I. J., Paulraj, A., \& Lado, A. A. (2014). Strategic purchasing, supply management, and firm performance. Journal of operations management, 22(5), 505-523. http://dx.doi.org/10.1016/j.jom.2004.06.002

Cheung, F. M., Cheung, S. F., Zhang, J., Leung, K., Leong, F., \& Huiyeh, K. (2008). Relevance of openness as a personality dimension in Chinese culture aspects of its cultural relevance. Journal of Cross-Cultural Psychology, 39(1), 81-108. http://dx.doi.org/10.1177/0022022107311968

Choo, A. S., Linderman, K. W., \& Schroeder, R. G. (2007). Method and context perspectives on learning and knowledge creation in quality management. Journal of Operations Management, 25(4), 918-931. http://dx.doi.org/10.1016/j.jom.2006.08.002

Choo, C., \& Bontis, N., (2002). The strategic management of intellectual capital and organization knowledge. New York: Oxford University Press.

Colurcio, M. (2009). TQM: a knowledge enabler?. The TQM Journal, 21(3), $236-248$. http://dx.doi.org/10.1108/17542730910953013

Crosby, P.B. (1996). Quality is free: The Art of Making Quality Certain. New American Library, New York.

Cummings, J. L. (2002). Knowledge transfer across R\&D units: an empirical investigation of the factors affecting successful knowledge transfer across intra-and inter-organizational units. Unpublished doctoral dissertation, George Washington University.

Dadfar, H., Staffan, B., Sedigheh, S., \& Ebadzadeh, S. (2013). Customer involvement in service production, delivery and quality. International Journal of Quality and Service Sciences, 5(1), 46-65. http://dx.doi.org/10.1108/17566691311316248

Danish, R., Asghar, A., \& Asghar, S. (2014). Factors of Knowledge Management in Banking Sector of Pakistan. Journal of Management Information System and E-commerce, 1(1), 41-49.

Darroch, J., \& McNaughton, R. (2005). Examining the link between knowledge management practices and types of innovation. Journal of intellectual capital, 3(3), 210-222. http://dx.doi.org/10.1108/14691930210435570

Davenport, T. H., \& Prusak, L. (1998). Working knowledge: how organizations manage what they know. Boston, Mass: Harvard Business School Press.

Debowski, S. (2006). Knowledge Management. John Wiley \& Sons Australia, Ltd.

Deming, W. E. (1986). Out of the Crisis. MIT Center for Advanced Engineering. Cambridge:MA, University Press.

Doorewaard, H., Van Hootegem, G., \& Huys, R. (2012). Team responsibility structure and team performance. Personnel review, 31(3), 356-370. http://dx.doi.org/10.1108/00483480210422750

Earl, M. (2001). Knowledge management strategies: Toward a taxonomy. Journal of management information systems, 18(1), 215-233.

Easton, G. S., \& Jarrell, S. L. (1998). The effects of Total Quality Management on corporate performance: An empirical investigation. The Journal of Business, 71(2), 253-307. http://dx.doi.org/10.1086/209744

Ehie, I., \& Sheu, C. (2005). Integrating six sigma and theory of constraints for continuous improvement: A case study. Journal of Manufacturing Technology Management, $542-553$. http://dx.doi.org/10.1108/17410380510600518 
El-Masri, M., Orozco, J., Tarhini, A., \& Tarhini, T. (2015). The Impact of IS-Business Alignment Practices on Organizational Choice of IS-Business Alignment Strategies. The 19th Pacific Asia Conference on Information Systems (PACIS 2015), Paper 215, Singapore, 6-9 July 2015.

Ford, D. P., \& Staples, S. (2010). Are full and partial knowledge sharing the same?. Journal of Knowledge Management, 14(3), 394-409. http://dx.doi.org/10.1108/13673271011050120

Fotopoulos, C. V., \& Psomas, E. L. (2010). The structural relationships between TQM factors and organizational performance. The TQM Journal, 22(5), 539-552. http://dx.doi.org/10.1108/17542731011072874

Frey, M. (2001), Happiness, Economy and Institutions. The Economic Journal, 110(4), 918-938.

Gagnon, M. A., Michael, J. H., Elser, N., \& Gyory, C. (2013). Seeing green in several ways: The interplay of entrepreneurial, sustainable and market orientations on executive scanning and small business performance. Journal of Marketing Development and Competitiveness, 7(3), 9-28.

Gertsen, F. (2001). How continuous improvement evolves as companies gain experience. International Journal of Technology Management, 22(4), 303-326. http://dx.doi.org/10.1504/IJTM.2001.002966

Gold, A.H., A. Malhotra, \&Segars, A. H. (2001). Knowledge management: An organizational capabilities perspective. Journal of Management Information Systems, 18(1), 185-214.

Gupta, B., Iyer, L. S., \& Aronson, J. E. (2000). Knowledge management: practices and challenges. Industrial Management \& Data Systems, 100(1), 17-21. http://dx.doi.org/10.1108/02635570010273018

Hajir, J. A., Obeidat, B. Y., \& Al-Dalahmeh, M. A. (2015). The Role of Knowledge Management Infrastructure in Enhancing Innovation at Mobile Telecommunication Companies in Jordan. European Journal of Social Sciences, 50(3), 313-330.

Hales, T. C. (2010). Cannonballs and honeycombs. Notices-American Mathematical Society, 47(4), 440-449.

Hamoud, M., Akour, M. A., \& Al-Salti, Z. (2016). Developing the Main Knowledge Management Process via Social Media in the IT Organisations: A Conceptual Perspective. International Journal of Business Administration, 7(5), 49-64.

Hassouna, M., Elyas, T., \& Abou Trab, M. S. (2015). Customer Churn in Mobile Markets: A Comparison of Techniques. International Business Research, 8(6), 224-237. http://dx.doi.org/10.5539/ibr.v8n6p224

Honarpour, A., Jusoh, A., \& Md Nor, K. (2012). Knowledge management, total quality management and innovation: A new look. Journal of Technology Management \& Innovation, 7(3), 22-31. http://dx.doi.org/10.4067/S0718-27242012000300003

Hung, R. Y. Y., Lien, B. Y. H., Fang, S. C., \& McLean, G. N. (2010). Knowledge as a facilitator for enhancing innovation performance through total quality management. Total Quality Management, 21(4), 425-438. http://dx.doi.org/10.1080/14783361003606795

Hung, R. Y. Y., Lien, B. Y. H., Yang, B., Wu, C. M., \& Kuo, Y. M. (2011). Impact of TQM and organizational learning on innovation performance in the high-tech industry. International business review, 20(2), 213-225. http://dx.doi.org/10.1016/j.ibusrev.2010.07.001

Ijaz, A., Kee, D. M. H., \& Irfan, S. M. (2012). Internal customer job satisfaction and role of TQM practices. Far East Journal of Psychology and Business, 6(2), 1-14.

Ju, T. L., Lin, B., Lin, C., \& Kuo, H. J. (2006). TQM critical factors and KM value chain activities. Total Quality Management \& Business Excellence, 17(3), 373-393. http://dx.doi.org/10.1080/14783360500451614

Kassim, N., \& Asiah Abdullah, N. (2010). The effect of perceived service quality dimensions on customer satisfaction, trust, and loyalty in e-commerce settings: A cross cultural analysis. Asia Pacific Journal of Marketing and Logistics, 22(3), 351-371. http://dx.doi.org/10.1108/13555851011062269

Kaynak, H. (2003). Total quality management and just-in-time purchasing: Their effects on performance of firms operating in the US. Garland, New York, NY, Taylor \& Francis.

Khusrow, U. (2001), Development of a framework for comparing performance improvement programs, (Doctoral dissertation), Massachusetts Institute of Technology.

Krogh, G. von, \& Roos, J. (2005). Conversation Management. European Management Journal, 13(4), 390-394. http://dx.doi.org/10.1016/0263-2373(95)00032-G

Liker, J. K., \& Hoseus, M. (2010). Human resource development in Toyota culture. International Journal of Human Resources Development and Management, 10(1), 34-50. http://dx.doi.org/10.1504/IJHRDM.2010.029445 
Lin, C., Wu, C. (2005). Managing knowledge contributed by ISO 9001: 2000. International Journal of Quality \& Reliability Management, 22(9), 968-985. http://dx.doi.org/10.1108/02656710510625239

Lin, H. F., \& Lee, G. G. (2005). Impact of organizational learning and knowledge management factors on e-business adoption. Management Decision, 43(2), 171-188. http://dx.doi.org/10.1108/00251740510581902

Lloria, M. B. (2008). A review of the main approaches to knowledge management. Knowledge Management Research \& Practice, 6(1), 77-89. http://dx.doi.org/10.1057/palgrave.kmrp.8500164

Maguad, B. A. (2006). The modern quality movement: Origins, development and trends. Total Quality Management \& Business Excellence, 17(2), 179-203. http://dx.doi.org/10.1080/14783360500450608

Masa'deh, R., Al-Dmour, R. H. \& Obeidat, B. Y. (2015). Strategic IT-Business Alignment as Managers' Explorative and Exploitative Strategies. European Scientific Journal, 11(7), 437-457.

Masa'deh, R., Gharaibeh, A., Tarhini, A. \& Obeidat, B. (2015). Knowledge Sharing Capability: A Literature Review. Fourth Scientific \& Research Conference on New Trends in Business, Management and Social Sciences, Istanbul, Turkey, 19-20 September 2015, pp. 1-16.

Masa'deh, R., Almajali, D., Obeidat, B.Y., Aqqad, N., \& Tarhini, A. (2016). The Role of Knowledge Management Infrastructure in Enhancing Job Satisfaction. International Journal of Public Administration, in press.

Masa'deh, R., Gharaibeh, A., \& Obeidat, B. (2015). Knowledge Sharing Capability: A Literature Review. Fourth Scientific \& Research Conference on New Trends in Business, Management and Social Sciences, Istanbul, Turkey, 19-20 September 2015, pp. 1-16. http://dx.doi.org/10.2139/ssrn.2696924

Masa'deh, R., Obeidat, B. Y., \& Al-Dmour, R. H. (2015). Knowledge Management Strategies as Intermediary Variables between IT-Business Strategic Alignment and Firm Performance. European Scientific Journal, 11(7), 344-368.

Masa'deh, R., Obeidat, B. Y., \& Tarhini, A. (2016). A Jordanian Empirical Study of The Associations Among Transformational Leadership, Transactional Leadership, Knowledge Sharing, Job Performance, and Firm Performance: A Structural Equation Modelling Approach. Journal of Management Development, 35(5), 681-705. http://dx.doi.org/10.1108/JMD-09-2015-0134

Masa'deh, R., Shannak, R., Maqableh, M., \& Tarhini, A. (2016). The Impact of Knowledge Management on Job Performance in Higher Education: The Case of the University of Jordan. Journal of Enterprise Information Management, 29(6), 25-43.

Meyer, J. P., \& Herscovitch, L. (2011). Commitment in the workplace: Toward a general model. Human Resource Management Review, 11, 299-326. http://dx.doi.org/10.1016/S1053-4822(00)00053-X

Molina, L. M., Lloréns-Montes, J., \& Ruiz-Moreno, A. (2007). Relationship between quality management practices and knowledge transfer. Journal of Operations Management, 25(3), 682-701. http://dx.doi.org/10.1016/j.jom.2006.04.007

Mondy, R. W. (2013). Human resource management (10th ed.). Boston: Pearson.

Montes, F., Moreno, A., \& Molina, A. (2003). An analysis of the relationship between quality and perceived innovation: "the case of financial firms". Industrial Management \& Data Systems, 103(8), 579-590. http://dx.doi.org/10.1108/02635570310497620

Nonaka I., \& Takeuchi, H. (1995). The Knowledge-Creating Company. Oxford University Press.

Oakland, J., \& Porter, L. (2004). Quality 21. Quality World, 30(1), 10-14.

Obeidat, B. Y., \& Abdallah, A. B. (2014). The relationships among human resource management practices, organizational commitment, and knowledge management processes: A structural equation modeling approach. International Journal of Business and Management, 9(3), 9-26. http://dx.doi.org/10.5539/ijbm.v9n3p9

Obeidat, B.Y., Al-Suradi, M., Masa'deh, R., \& Tarhini, A. (2016). The Impact of Knowledge Management on Innovation: An Empirical Study on Jordanian Consultancy Firms. Management Research Review, 39 (10), 1214-1238. http://dx.doi.org/10.1108/MRR-09-2015-0214

Obeidat, B.Y., Al-Sarayrah, S., Tarhini, A., Al-Dmour, R. H., \& Al-Salti, Z. (2016). Cultural Influence on Strategic Human Resource Management Practices: A Jordanian case study. International Business Research, 9(10), $33-50$.

Obeidat, B.Y., Al-Suradi, M., Masa'deh, R., \& Tarhini, A. (2016). The Impact of Knowledge Management on Innovation: An Empirical Study on Jordanian Consultancy Firms. Management Research Review, 39(10), 22-38. http://dx.doi.org/10.1108/MRR-09-2015-0214 
O'dell, C., \& Grayson, C. J. (2008). If only we knew what we know: Identification and transfer of internal best practices. California Management Review, 40(3), 154-174. http://dx.doi.org/10.2307/41165948

Orozco, J., Tarhini, A., Masa'deh, R., \& Tarhini, T. (2015). A framework of IS/business alignment management practices to improve the design of IT Governance architectures. International Journal of Business and Management, 10(4), 1-12. http://dx.doi.org/10.5539/ijbm.v10n4p1

Pacharapha, T., \& Vathanophas, R. (2012). Knowledge acquisition: the roles of perceived value of knowledge content and source. Journal of Knowledge Management, 16(5), 724-739. http://dx.doi.org/10.1108/13673271211262772

Pencarelli, T., Splendiani, S., \& Cini, D. (2013). Quality and value in university services. International Journal of Quality and Service Sciences, 5(2), 140-153. http://dx.doi.org/10.1108/IJQSS-03-2013-0014

Powell, T. C. (1995). Total quality management as competitive advantage: a review and empirical study. Strategic Management Journal, 16(1), 15-37. http://dx.doi.org/10.1002/smj.4250160105

Rai, A. K. (2013). Customer relationship management: Concepts and cases (2nd ed.). New Delhi: PHI Learning.

Salas, E., Cooke, N., \& Groman, J. (2010). The science of team performance: Progress and the need for more. The Journal of the Human Factors and Ergonomics Society, 52(2), 344-346.

Salas, E., Wilson, K. A., Murphy, C. E., King, H., \& Salisbury, M. (2008). Communicating, coordinating, and cooperating when lives depend on it: Tips for teamwork. The Joint Commission Journal on Quality and Patient Safety, 34(6), 333-341. http://dx.doi.org/10.1177/0018720810374614

Sanzo, M. J., Álvarez, L. I., Rey, M., \& García, N. (2012). Perceptions of top management commitment to innovation and R\&D-marketing relationship effectiveness: Do they affect CSR?. Annals of Public and Cooperative Economics, 83(3), 383-405. http://dx.doi.org/10.1111/j.1467-8292.2012.00468.x

Shannak, R. O., Ra'ed, M., \& Ali, M. (2012). Knowledge management strategy building: Literature review. European Scientific Journal, 8(15), 143-168.

Shannak, R., Al-Zu'bi, Z., Alshurideh, M., \& Altamony, H. (2012). A theoretical perspective on the relationship between knowledge management systems, customer knowledge management, and firm competitive advantage. European Journal of Social Sciences, 32(4), 520-532.

Singh, H. (2013). Continuous Improvement Strategies: An Overview. IUP Journal of Operations Management, 12(1), 32.

Stein, E. W., \& Zwass, V. (2005). Actualizing organizational memory with information systems. Information Systems Research, 16(2), 85-117.

Stewart, D., \& Waddell, D. (2008). Knowledge Management: The fundamental component for delivery of quality. Total Quality Management, 19(9), 987-996. http://dx.doi.org/10.1080/14783360802227803

Su, C. H., Tsai, A., \& Hsu, C. L. (2010). The TQM extension: Total customer relationship management. Total Quality Management, 21(1), 79-92. http://dx.doi.org/10.1080/14783360903492678

Tarhini, A., Ammar, H., Tarhini, T. \& Masa'deh, R. (2015). Analysis of the Critical Success Factors for Enterprise Resource Planning Implementation from Stakeholders' Perspective: A Systematic Review. International Business Research, 8 (4), 25-40. http://dx.doi.org/10.5539/ibr.v8n4p25

Tayal, A., Coleman, T. F., \& Li, Y. (2015). Rankrc: Large-scale nonlinear rare class ranking. IEEE Transactions on Knowledge and Data Engineering, 27(12), 3347-3359. http://dx.doi.org/10.1109/TKDE.2015.2453171

Thompson, L. L. (2011). Making the team: A guide for managers (4th ed.). Upper Saddle River, NJ: Pearson-Prentice Hall.

Tiwana, A. (2010). The knowledge management toolkit: Practical techniques for building knowledge management system. Upper Saddle River, NJ: Prentice Hall.

Tsai, W. (2011). Knowledge transfer in intraorganizational networks: Effects of network position and absorptive capacity on business unit innovation and performance. Academy of Management Journal, 44(5), 996-1004. http://dx.doi.org/10.2307/3069443

Turban, E., Sharda, R., \& D. Delen, (2011). Decision Support and Business Intelligence Systems (9th ed.). Boston: USA, Pearson.

Wang, C. H., Chen, K. Y., \& Chen, S. C. (2012). Total quality management, market orientation and hotel performance: The moderating effects of external environmental factors. International Journal of Hospitality 
Management, 31(1), 119-129. http://dx.doi.org/10.1016/j.ijhm.2011.03.013

Wiig, K. M. (1997). Knowledge management: an introduction and perspective. Journal of knowledge Management, 1(1), 6-14. http://dx.doi.org/10.1108/13673279710800682

Wilson, T. D. (2010). Models in information behaviour research. Journal of documentation, 55(3), $249-270$. http://dx.doi.org/10.1108/EUM0000000007145

Yang, B. (2003). Toward a holistic theory of knowledge and adult learning. Human Resource Development Review, 2(2), 106-129. http://dx.doi.org/10.1177/1534484303002002002

Young, R. (2013). Knowledge Management for the Public Sector. Tokyo, Japan: Asian Productivity Organziation.

Young, R., \& Jordan, E. (2008). Top management support: Mantra or necessity?. International Journal of Project Management, 26(7), 713-725. http://dx.doi.org/10.1016/j.ijproman.2008.06.001 